\title{
Go for a Woman if you Feel Risky: Evidence from Gender Diversity in MFIs ${ }^{I}$
}

\author{
Alsu Khisamitova \\ Research intern \\ $\underline{\text { ORCID }}$ \\ E-mail: khisamitova@mail.ru \\ Corporate Finance Center, National Research University Higher School ofEconomics, Moscow, Russia
}

\section{Anastasia Stepanova}

Research fellow

$\underline{\text { ORCID }}$

E-mail: anastasianstepanova@gmail.com

Corporate Finance Center, National Research University Higher School ofEconomics, Moscow, Russia

\author{
Maria Kokoreva \\ Research fellow \\ ORCID \\ E-mail: mskokoreva@gmail.com
}

Corporate Finance Center, National Research University Higher School ofEconomics, Moscow, Russia

Journal of Corporate Finance Research, Vol. 13, No. 3, pp. 19-34 (2019)

DOI: $10.17323 /$ j.jcfr.2073-0438.13.3.2019.19-34

Received 27 May 2019 | Peer-reviewed 17 June 2019 | Accepted 3 September 2019

The journal is an open access journal which means that everybody can read, download, copy, distribute, print, search, or link to the full texts of these articles in accordance with CC Licence type: Attribution 4.0 International (CC BY 4.0 http://creativecommons.org/licenses/by/4.0/).

\footnotetext{
I This paper is a composition from a research project implemented within NRU HSE's Annual Thematic Plan for Basic and Applied Research. Any opinions or claims contained in this paper do not necessarily reflect the views of HSE.
} 


\section{Go for a Woman if you Feel Risky: Evidence from Gender Diversity in MFIs}

\section{Abstract}

This paper contributes to the literature on management and corporate governance in microfinance institutions. The microfinance market is one of the rare markets with a large representation of women in management and governance roles. The objective of our paper is to reveal the effects of women's presence on the financial and social performance of microfinance institutions.

To achieve this, we develop a model that allows for capturing the influence of gender diversity in the microfinance field whilst controlling for risks. We focus on the role of women as loan officers, on boards of directors, and involved in managing the creation of microfinance institutions. Our model utilises two sets of panel data regressions, one for social performance and one for financial performance, and is tested on data from 193 microfinance institutions across Eastern Europe and Central Asia for the financial years 2010 through 2014.

The results of our investigation indicate that the activity of female members of management, CEOs, and boards of directors could increase performance indicators for riskier microfinance institutions. This is illustrated particularly in the case of projects with greater stakes in portfolios that are more than 90 days in arrears. We also provide evidence that women on boards tend more towards promoting a strategy utilising large quantities of small loans with greater interest. The social performance of microfinance institutions is crucially determined by the microfinance institutions' size. For the largest microfinance institutions, questions of social performance lie in the field of boards of directors, while smaller institutions' social performance is mostly driven by CEOs and staff, with significant evidence of a positive female influence on performance indicators.

The novelty of this study is demonstrated the scope of our research. We combine several contemporary issues of peculiar cross-disciplinary interest, and offer succinct and compelling results which will be of immediate applicability in a wide range of academic and professional fields. Our results will be of interest to scholars of gender, social studies, psychology, business, corporate structure, and more. More specifically, we add to the evolving sub-field of study of microfinance institutions, which has the potential to develop rapidly in the near future. This paper represents a cross-section of commercial and business research across a wide territory, with a large sample size, and provides compelling conclusions, which add to these fields of study by both validating existing research, and highlighting new areas for future analysis.

Key words: microfinance institutions, corporate governance, performance, gender diversity, risk

JEL classification: G30, G32, G34 


\section{Introduction}

Microfinance institutions (MFIs) have been developing in emerging markets since the 1980s. They provide different kinds of financial services (loans, deposits, insurance, social intermediation and payment services) to representatives of low-income families and micro-entrepreneurs. Nowadays, microfinance institutions are of particular interest to researchers and market-watchers as they have the potential to become an innovative platform, due to mobile phone penetration, new players in the market, and massive investments in FinTech [1]. The social orientation of MFIs leads to a reduction in poverty and unemployment in the country of operation. Therefore, we will treat MFIs as not only banking entities, but also as a development tool [2]. Social activity is aimed towards providing an opportunity to vulnerable populations to live a fuller life. Introducing people to the financial services market increases the activity of citizens and leads to a certain social recovery, which contributes to removing some tensions in society.

Despite MFIs playing a significant social role, they are still commercial enterprises, i.e. they should generate profit and have a payback policy that meets investors' requirements. They should maintain a financial sustainability that allows them to continue fulfilling their social mission. Thus, MFIs should find a balance between financial and social performance. A sound policy in corporate governance helps to achieve this goal; therefore, in this paper we investigate the influence of corporate governance on the social and financial performance of MFIs in emerging markets.

Microfinance activity is to a large extent a female business [3; 4]. First of all, women represent the largest market for MFIs. Women are considered capable fighters against poverty, as they are more likely to reinvest their earnings in their families or business. Likewise, microfinance may be considered a 'woman's business' as the proportion of female directors or managers in MFIs is higher than in other financial institutions. Considering the peculiar trend of women's risk-aversion in decision-making, it is particularly crucial to investigate the effect of this female presence in the sector of MFIs, where risks are quite different from risks in other sectors. Thus, our paper focuses on gender diversity in the framework of corporate governance and management mechanisms in order to reveal the effects of women's presence on the financial and social performance of MFIs, while controlling for appropriate risk factors.

We find out that gender diversity makes a difference in the performance of MFIs with high risk portfolios. For such firms, women can increase performance and mitigate risks. We also document female influence on social performance. For larger MFIs this influence is lower and is driven by the female membership in boards of directors, while for smaller MFIs female CEOs and staff could add more to the social performance.

This paper has the following structure. In the next section, we provide a review of the existing literature. In other section we develop appropriate hypotheses and describe the methodology. The results are presented in following section. Finally, we present the discussion and our conclusions.

\section{Literature Review}

After the global financial turmoil of 2007-2008, the problem of corporate governance in financial institutions (FI) became an acutely popular field of study. It is considered that if the corporate governance of an FI is sound, it means that the FI examines the firms that it plans to fund and allocates capital efficiently [5]. When receiving money, the company invests it into the business, and expands its activity, which improves the economic development of the country. The same logic can be applied to microfinance institutions. On the contrary, if the corporate governance of an FI is at a low level, the FI faces a problem of efficiently allocating the savings of its society, with the potential for a destructive impact on the corporate governance of the firms they fund. This distress is likely to expand to the adjacent financial environment, which might in turn lead to credit restrictions with a significant effect on other industries [6]. Therefore, the corporate governance of FIs influences not only the activity of the FIs, but also non-financial companies and the economy as a whole (e.g. see [7] regarding the influence of banks on the corporate governance of loan-receiving firms).

In most countries, the government strictly regulates FI operations. This is the second reason for distinguishing the corporate governance of financial firms from that of non-financial ones. A significant quantity of FIs have to conform to international standards such as Basel I, Basel II, etc. That is why many rules change the corporate governance of financial firms and make it specific [5].

Moreover, C.H. Furfine proved that the information asymmetry is larger in FIs in comparison with firms from other industries [8]. That is especially important for our study, since in MFIs we face even higher levels of informational asymmetry than in FIs; and the asymmetry level is higher again in the emerging markets we are considering [9].

To sum up, while in this paper we focus on the role of women in the governance of MFIs', it is worth considering papers focused on corporate governance in the financial sector to realise the gap between governance in non-financial firms and financial institutions.

\section{Corporate governance in the financial sector}

As of the time of publishing, the majority of research papers focus on the relationship of corporate governance features (board size, CEO duality, board independence) and corporate performance. So, what do we know about corporate governance in FIs?

We will start with board size, since the number of directors influences both the speed of decision-making and the human capital of the board. D.R. Dalton et al. report that boards with a large number of directors increase the possibility of beneficial activity because they enhance the variety of relevant knowledge, expertise, and the resources that are available to the firm [10]. In contrast, there is another popular view that large boards are ineffective. A large size may inhibit the board from solving current 
issues quickly because the board needs more time to come to a common decision. What is more, there is a possibility that free-riding problems amongst directors can appear [11]. For example, R.B. Adams and D. Ferreira analyse 5707 directorships during the years 1986-1999 and prove that board size is positively related to problems with attendance [12]. The larger the board is, the more free-riding behavior may occur.

The picture in an FI looks quite similar as concerns non-financial companies. Jensen's ideas about large, inefficient board with poor coordination and low speed of decision-making work for the FIs as well $[11 ; 13]$.

Contradictory evidence (i.e. non-significant influence of board size) is provided by $[14,15]$. These findings lead to the hypothesis that the relationship between board size and firm performance can be non-linear. H. Grove et al. expect that the size of the board size an impact on financial performance by means of a concave relationship [16]. They think that, initially, when the board size goes up, it might bring more expertise; however, after reaching the breaking point, the growth of the board can lead to an increase in agency conflicts and FI performance can be impaired. The researchers validate their hypothesis. However, P. De Andrés and E. Vallelado obtain contradictory results. According to their research, the efficiency of the FI decreases as the number of directors rises, and after a defined point the effect changes: the performance goes up as the number of directors declines [17].

R.B. Adams and H. Mehran analyse 35 BHCs (bank holding companies) and conclude that more members in the board correlates with an increase in the performance of the $\mathrm{BHC}$, if the directors from the main board also sit on the subsidiary board [18]. The explanation of this phenomenon can be the following: being a member of the main and subsidiary board, directors comprehend the situation better at different stages of organisation and can therefore develop a plan or a strategy more appropriate for that BHC.

In emerging markers, we face more homogenous findings. Tai's research indicates that the board size positively affects the performance of national banks in the Gulf Cooperation Council (GCC) countries [19]. The same result is obtained byA.B.O.Onakoya and co-authors, based on the analysis of Nigerian banks [20].

\section{What do we know about role of women in financial firms?}

Board diversity, especially gender diversity, may influence firm performance significantly, since it is supposed that women differ from men in leadership behaviour, risk-taking, etc. S. Nielsen and M. Huse [21] emphasise that women's performance in the board depends on the tasks they are responsible for. The more female members there are in the board, the better the board's strategic control is, but there is no similar relationship with board operational control. Likewise, they obtain that the presence of women makes conflicts fade in the board, hence, there is a higher possibility of improving firm performance.
The hypothesis that the women are more risk-averse in investment decision-making is proved by [22;23]. M. Niederle and L. Vesterlund state that women are also less likely to be overconfident than men [24]. However, some investigations obtain the opposite result. For example, R.B. Adams and P. Funk demonstrate that female directors are more prone to make risky decisions [25].

At the same time, as we already mentioned, the microfinance business is to a large extent a female-dominated business [3]. Women are more likely to reinvest their earnings in their families or business, and that makes them good contributors to the social performance of financial institutions.

Finally, the fact that the proportion of female directors or managers in MFIs is higher [4] than in other sectors is worth being studied. Considering the peculiarity of women's risk-aversion in decision-making, it is important to investigate women's role in the MFI sector, where informational asymmetry (and risks) are higher than in traditional commercial FIs.

\section{What do we know about corporate governance and the role of women in MFIs?}

For MFIs, corporate governance is important not only for financial performance, but also for social performance. The board should help to find a balance between the social role and economic goals.

Corporate governance in MFIs is not a settled issue at the moment. G. Estapé-Dubreuil and C. Torreguitart-Mirada [26] investigate the difference in governance mechanisms between MFIs with diverse legal statuses (non-governmental organisations, regulated commercial financial institutions) and study the relation between governance mechanisms and the results of MFIs' missions, such as providing banking services to low-income families and micro-entrepreneurs and maintaining financial sustainability. The researchers consider not only financial performance, but also social performance. They show that corporate governance has a more profound effect on social performance than on financial performance in MFIs. They found that the instruments in the ownership-board dimension raise the enhancement of all measurements of social performance. On the contrary, governance mechanisms targeting the staff of MFIs (such as incentives and fair practices in labour) have no impact either on its social performance or on its financial performance.

R. Gohar and A. Batool investigate MFIs in Pakistan [27]. They find that the productivity of the MFI, the firm size of the MFI, individual lending, the MFI's age, and regulations, have positive significant impact on financial performance. However, the board size and CEO/chair duality have negative effects. The presence of a female director, regulation, firm size and urban market influence social performance positively, while the board size affects negatively the outreach. 
Some investigators examine groups of countries which are quite similar, e.g. the activity of MFIs in East Africa is studied in N. Mori et al. [28]. The authors explore three unique characteristics of MFIs: regulation status, international influence and founder management. They find that regulated MFIs have larger boards, higher board independence and less gender diversification. The same results are obtained for internationally influenced MFIs. It is also said that MFIs managed by founders have a higher level of board gender diversity.

R. Mersland and R.Ø. Strøm also consider the influence of different factors on social performance and financial performance [29]. The results obtained reveal that financial performance improves when the board has an internal board auditor and have local rather than international directors. As regards the ownership type, it does not affect financial performance, in contrast to the work of G. Estapé-Dubreuil and C/ Torreguitart-Mirada [26]. They find that a microfinance institution is better served with a female CEO. Furthermore, social performance rises with $\mathrm{CEO} /$ chairman duality because the number of credit clients increases. However, the level of outreach goes down with individual loans for both average loan size and the number of credit clients.

With this study, we would like to fill in the gap in the literature investigating corporate governance in MFIs in emerging countries, with a special focus on gender diversity. We demonstrate the role of women in the financial and social performance of MFIs. Thus, to capture the effects of women's presence on risk and the performance of MFIs, we develop the following hypotheses.

Hypothesis 1:A female presence in the management and governance of an MFI leads to greater financial performance in emerging markets.

Hypothesis 2:A female presence in the management and governance of an MFI leads to greater social performance in emerging markets.

In the literature review we discussed that most researchers consider women to be more risk averse. Women are seen as more careful and might be less overconfident than men [24]. It has been demonstrated that the presence of women at different levels of management reduces firm risk and improves firm performance [30]. We expect to receive similar results. We also suppose that the influence of women is greater in MFIs which deal in riskier projects, where female risk-averseness could be more beneficial.

A positive relationship between female membership in the board and social outreach was discovered [3]. This may have happened because women think more about social outreach than men and try to help indigent people. We anticipate that the role of women on boards could be not as significant as the role of a female CEO or females in management, since the governance mechanisms in emerging markets are not developed to the same extent as in developed markets.

\section{Methodology and data}

\section{Data}

Our research is conducted on data from MFIs across Eastern Europe and Central Asia ${ }^{1}$. This region includes mostly emerging national economies that have similar history, development, and economy, which assists us in making the corresponding analysis and compiling the relevant results.

After refining the available data based on available information on the governance and management of MFIs, our sample was restricted to 193 microfinance institutions for 2010-2014 years.

To source our information, we used the Microfinance Information Exchange (MIX), and the information from the official websites of different MFIs to collect data. MIX provides reliable data because its specialists collect data from financial statements, and follows the International Financial Reporting Standards (IFRS), including management reports and other documents which contain relevant information. Furthermore, the data from MFIs is monitored constantly.

\section{Description of variables and methodology}

Our study assumes two steps, and hence two major sets of regressions to be tested. The first step refers to the impact of a female presence in corporate governance and management on financial performance (1), and the second set measures the influence of women on social performance (2):

$$
\begin{aligned}
& \text { Financial } \operatorname{proxy}_{\mathrm{it}}=\beta_{1}+\beta_{2} \operatorname{lev}_{\mathrm{it}}+ \\
& +\beta_{3} \operatorname{par} 90_{\mathrm{it}}+\beta_{4} \mathrm{wceo}_{\mathrm{it}}+ \\
& +\beta_{5} \mathrm{wboad} \_\mathrm{pc}_{\mathrm{it}}+\beta_{6} \mathrm{wman} \_\mathrm{pc}_{\mathrm{it}}+ \\
& +\beta_{6} \text { wstaff_pc }_{\text {it }}+\beta_{8} \text { board_size }_{\text {it }}+ \\
& +\beta_{9} \text { firm_size }_{\mathrm{it}}+\beta_{10} \text { opex_loan }_{\mathrm{it}}+ \\
& +\beta_{11} \text { operating_ortfo }{ }_{\mathrm{it}}+\beta_{12} \text { age }_{\mathrm{it}}+ \\
& +\beta_{13} \text { GDP_PPP }_{\mathrm{it}}+\beta_{14} \text { interraction }_{\mathrm{it}}+\varepsilon_{\mathrm{it}}
\end{aligned}
$$

$$
\begin{aligned}
& \text { Social_proxy }{ }_{\mathrm{it}}=\alpha_{1}+\alpha_{2} \text { offices }_{\mathrm{it}}+ \\
& +\alpha_{3} \operatorname{par} 90_{\mathrm{it}-1}+\alpha_{4} \mathrm{wceo}_{\mathrm{it}}+
\end{aligned}
$$

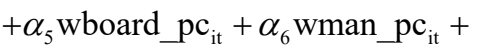

$$
\begin{aligned}
& +\alpha_{7} \text { wstaff_pc }_{\text {it }}+\alpha_{8} \text { board_size }_{\text {it }}+ \\
& +\alpha_{9} \text { firm_size }_{\text {it }}+\alpha_{10} \text { interraction }_{\text {it }_{\text {it }}}+ \\
& +\alpha_{11} \text { operating_ortfo }{ }_{\mathrm{it}}+\alpha_{12} \mathrm{age}_{\mathrm{it}}+ \\
& +\alpha_{13} \text { GDP_PPP }_{\text {it }}+\mu_{\text {it }}
\end{aligned}
$$

A detailed description of the variables and the descriptive statistics may be found in Appendix 1 (see Tables 1 and 2).

${ }^{1}$ See: https://www.themix.org/mixmarket/countries-regions/eastern-europe-and-central-asia 
Dependent variables are divided into 2 groups depending on the type of regression.

The first group of regressions deals with the financial performance of MFIs measured as return on assets, return on equity, operational self-sufficiency, profit margin, and portfolio yield [29; 27].

The second group considers the social performance of MFIs, which should be measured in a way to reflect six aspects of social outreach of microfinance activity: worth to clients, cost to clients, depth, breadth, length, and scope [31]. In our research, we measure performance by two of these measures: depth and breadth.

The depth of outreach is defined as the estimated value of a net gain of a particular client. The indirect proxies are used more often than the direct indicators of depth through income or wealth because of the difficulty of accurately gauging the measurement. That is why researchers prefer to use, as indicators, sex, location, ethnicity, housing, and access to public services. However, the most common proxy for depth is loan size. The best way to measure this is to use the average amount outstanding. If the loan size is small, it means that the depth is great, because there is a greater possibility that the person is poor.

The next aspect is the breadth of outreach. This is measured by the number of clients. We also investigate the growth in the number of borrowers separately.

Additionally, the investigators tend to use one more proxy for defining social performance - the percentage of female borrowers. This indicator is used because it has been proven that females are almost three times more likely to reinvest their earnings in the business and in their families than men are [32].

We focus particularly on the interrelation of women's influence in cases of high or low risks. Our measure of risk is 'portfolio at risk $>90$ days ratio'. The portfolio at risk > 90 days ratio is the proportion of overdue loans (overdue by more than 90 days) in the loan portfolio. This coefficient demonstrates that a rise in overdue credit leads to an increase in the possibility of the failure to pay back the loan, increasing the risk to the MFI. To capture the influence of women in the presence of risks, we add interactive terms to basic regressions. As interaction variables, we include the interactions between the risk measure par90 and the percentage of women in management, or the presence of female CEOs.

Control variables include operating expense-to-loan portfolio ratio, leverage, the number of offices, the firm size, the age, and GDP per capita.

The correlation matrix is presented in Appendix 2, Table 3.

\section{Results}

Our final results are presented in Tables 4-7, and 8 of Appendices 3 and 4 .

We start with the results of the financial performance of MFIs with regard to gender diversity (Tables 4 and 5).
We measured performance with profit margin, ROA, ROE, nominal yield on gross portfolio and operational self-sufficiency. Our results show that MFIs with a greater fraction of the portfolio with more than 90 days in arrears tend to have poorer performance. Although that result could be regarded as self-evident, as regards profit margin and ROA we can see that despite the risk, the percentage of women in management (2) increases performance. The same is true for the cases of female CEO presence, provided the risks are greater than average (the average value of par90 is 0.048 in our sample). This result is especially strong for small MFIs (3).

We also discovered the positive influence of women on boards on measures of performance, calculated as ROA, $\mathrm{ROE}$, and yield on gross portfolio- i.e. the measures that are highly dependent on MFI strategy. This influence is correlated with the greatest for yield in gross terms vis$\grave{a}$-vis the MFI portfolio. To prove that point, we looked closer at the relationship between the gender diversity in boards and MFIs strategies. As could be seen in Table 6, where we measured the characteristics of loans in MFIs with the highest and lowest quartile of women with a stake in boards in directors, MFIs with more women on board try to promote the strategy of more small loans with greater interest, while for MFIs with lower gender diversity we see larger loans with lower interest rates. As a result, the yield in terms of the overall (gross) portfolio is greater in MFIs with more women on boards.

The yield on gross portfolio is the only measure influenced by the macroeconomic conditions measured by GDP per capita, which is reasonable, since the interest on loan portfolio is highly dependent on the macroeconomic situation in a country. For the remaining measures the internal methods of management and governance matter more(Table 6).

We found at first glance a controversial result for operating self-sufficiency, where the presence of a male CEO is seen to improve performance (when calculating the influence of male CEO interaction with risk measures). Although this could be regarded as evidence that female CEOs care more about profit margins while male CEO care more about cost efficiency, we suppose that this could most likely be a result of company size. As the MFI becomes larger, it moves from the strategy of increasing margin to increasing cost efficiency as well. We checked this idea by measuring the effect separately for small companies (12) in order see if we lose the significance of CEO gender on operating self-sufficiency. The idea of the effect is as follows: the greater the size of the MFI, the more probability there will be a male CEO. The same, however, is not true for margin measures (3) where women CEOs could mitigate the risks effects on profit margin.

Finally, we found a strong negative influence of leverage on financial performance for all measures except ROE and yield on gross portfolio. We believe that this result is reasonable, since leverage decreases the overall solvency of MFI, which leads to lower efficiency. On the other hand, by means of leverage, MFIs could increase the return to 
shareholders (ROE) though increasing risks. The yield on gross portfolio is mostly determined by macro conditions, and hence this performance measure is not that influenced by leverage.

In summing up, we could state that the presence of women in management roles of MFIs and in governance roles could be especially profitable for MFIs in the high risks category, where women are seen to propose and implement more secure strategies.

Next, we present the results of our evaluation of female presence on social performance (Tables 7 and 8, Appendix 4).

We start with the average loan measure, and find a contradictory result to our previous findings. In this case, a greater stake of female managers leads to larger volume of average loans (1). To separate this result from the size effect, we separately examined firms of lower than average size (2), and a subsample of $25 \%$ of the largest companies (3). We found that women's presence can lead to a greater-than-average loan, but only in largest MFIs. On average, in these MFIs you may expect to see a male CEO, and management who care more about cost efficiency. For these MFIs, women could affect a change by increasing the size of the average loan. Still, we could state that to have deeper results, it may be prudent to look at the average loan amount per borrower. As we can see at (4), the gender diversity in management or governance does not influence the average loan per borrower. On the other hand, we can see the influence of firm size, firm age, and GDP per capita, as well as the number of offices. Supposing that the size effect here could also necessitate different models for gauging social performance, we distinguished the results for $50 \%$ of the largest (4) and smallest (5) companies by median size. We found out that for the largest firms, social performance is considered at board level, where women on board tend to lower the high levels of average loans. For smaller firms, we see that the influence of a $\mathrm{CEO}$ is greater, and a female CEO (not a manager of the board) tends to increase the size of small average loans. Thus, the social performance is mostly determined by CEO in small MFIs, whereas in larger MFIs it is determined by decisions of the board.

The number of borrowers (7) is often considered to be the fundamental measure of social performance. Still, it is again highly dependent on the firm size: for the largest MFIs we usually see a male CEO and a greater number of borrowers. Thus, we propose the measure of growth in the number of borrowers as a more representative value. We found out that if we look at the subsample of small and medium firms (9), a female CEO increases the growth in borrowers' numbers, whereas for $25 \%$ of the largest MFIs this is not the aim of the strategy, and so we see a relatively low quality in the regression on the whole sample (8). Still, we see that for all subsamples the number of offices matter, which is rational, since this would increase the probability of new customers for the MFI. Finally, we got the result, that the percentage of female borrowers could be greater in MFIs with more female staff and more wom- en on board (10). We see also that younger MFIs tend to have more female borrowers, however, this could be a result of male borrowers' choice to patronise older and more renowned MFIs.

\section{Conclusion}

This paper provides results of our research into MFIs' corporate governance and the influence of management on financial and social performance in Eastern Europe and Central Asia. We pay particular attention to the presence of women in management and governance roles in MFIs in order to show that the notably high presence of women in this industry is reasonable. We conduct am empirical analysis on the data from 193 MFIs over the period 2010 to 2014, as provided by the MIX database.

Our results provide insights into the influence of females in the financial and social performance of MFIs in Central Europe and Eastern Asia. We found out that women could be especially efficient in MFIs with higher levels of risk. In such MFIs female CEOs increase the quality of performance under various commercially significant categories. Female influence is also beneficial in small MFIs. For large and solvent MFIs the influence of women's presence is not as significant. We also show that women in boards tend to mitigate risks and tend towards developing a strategy of a large volume of small loans, which is also an indicator of social performance and engagement.

The results on social performance are highly influenced by the size effect. Still, we may conclude that the female role is crucial in staff and CEO positions for smaller MFIs, and in board positions for larger ones.

Overall, our results coincide with the suggestions of previous researchers that women are more risk averse, and thus we show that their presence is highly important for MFIs with a high level of risky commercial engagements, or for small MFIs where governance mechanisms are not so strong.

\section{References}

1. World Bank. Revolutionizing Microfinance: Insights from the 2017 Global Symposium on Microfinance (2017). World Bank Report.http://pubdocs. worldbank.org/en/332301505318076916/GSM2017Synthesis-report-draft-August-9th-2017-Final.pdf

2. Ledgerwood J. Microfinance Handbook: An Institutional and Financial Perspective. World Bank Publications. Washington DC. 2000.

3. Strøm R.Ø., D'Espallier B., Mersland R. Female leadership, performance, and governance in microfinance institutions. Journal of Banking \& Finance. 2014; 42:60-75.

4. Garikipati S., Johnson S., Guérin I., Szafarz A. Microfinance and Gender: Issues, Challenges and The Road Ahead. The Journal of Development Studies. 2017; 53(5): 641-648 
5. Levine R. The corporate governance of banks: A concise discussion of concepts and evidence. 2003; 3404: World Bank Publications, Washington DC.

6. Ukaegbu B., Isaiah O. The determinants of capital structure: A comparison of financial and nonfinancial firms in a regulated developing country - Nigeria. African Journal of Economic and Management Studies. 2014; 5(3): 341-368.

7. Qian M., Yeung B.Y. Bank financing and corporate governance. Journal of Corporate Finance. 2015; 32: $258-270$.

8. Furfine C.H. Banks as monitors of other banks: Evidence from the Overnight Federal Funds Market. Journal of Business. 2001; 74: 33-57.

9. Bekaert G., Harvey C.R. Emerging markets finance. Journal of Empirical Finance. 2003; 10:3-55.

10. Dalton D.R., Daily C.M., Johnson J.L., Ellstrand A.E. Number of directors and financial performance: a meta-analysis. Academy of Management Journal. 1999; 42(6):674-686.

11. Jensen M.C. The modern industrial revolution, exit, and the failure of internal control systems. The Journal of Finance. 1973; 48(3):831-880.

12. Adams R. B., Ferreira D. Regulatory pressure and bank directors' incentives to attend board meetings. International Review of Finance. 2012; 12(1):227-248.

13. Wang W-K., Lu W-M., Lin Y-L. Does corporate governance play an important role in $\mathrm{BHC}$ performance? Evidence from the U.S. Economic Modelling. 2012; 29(3): 751-760.

14. Erkens D. H., Hung M., Pedro Matos P. Corporate governance in the 2007-2008 financial crisis: Evidence from financial institutions worldwide. Journal of Corporate Finance. 2012; 18(2): 389-411.

15. Berger A. N., Imbierowicz B., Rauch C. The roles of corporate governance in bank failures during the recent financial crisis. Journal of Money, Credit and Banking. 2016; 48(4): 729-770.

16. Grove H., Patelli L., Victoravich L.M., Xu P. Corporate governance and performance in the wake of the financial crisis: Evidence from US commercial banks. Corporate Governance: An International Review. 2011; 19(5): 418-436.

17. Andrés (de) P., Vallelado E. Corporate governance in banking: The role of the boards of directors. Journal of Banking and Finance. 2008; 32 (12): 2570-2580.

18. Adams R.B., Mehran H. Bank board structure and performance: Evidence for large bank holding companies. Journal of Financial Intermediation. 2012; 21: 243-267.

19. Tai L. The Impact of Corporate Governance on the Efficiency and Financial Performance of GCC National Banks. Middle East Journal of Business. 2015; 10(1): 12-18.

20. Onakoya A.B., Fasanya I., Ikenna O.D. Corporate
Governance as Correlate for Firm Performance: A Pooled OLS Investigation of Selected Nigerian Banks. The IUP Journal of Corporate Governance. 2014; 13(1): 7-18.

21. Nielsen S., Morten H. The contribution of women on boards of directors: Going beyond the surface. Corporate Governance: An International Review. 2010; 18(2):136-148.

22. Barsky R.B., Juster F.T., Kimball M.S., Shapiro M.D. Preference parameters and behavioral heterogeneity: An experimental approach in the health and retirement study. The Quarterly Journal of Economics. 1997; 112(2): 537-79.

23. Sunden, A.E., Surette, B.J. Gender differences in the allocation of assets in retirement savings plans. The American Economic Review. 1998; 88(2): 207-211.

24. Niederle M., Vesterlund L. Do women shy away from competition? Do men compete too much? The Quarterly Journal of Economics. 2007; 122(3):10671101.

25. Adams, R.B., Funk, P. Beyond the glass ceiling: Does gender matter?. Management science. 2012; 58(2): 219-235.

26. E-Dubreuil', Estap ` G., Torreguitart-Mirada C. Governance mechanisms, social performance disclosure and performance in microfinance: Does legal status matter? Annals of Public and Cooperative Economics. 2015; 86(1):137 - 155.

27. Gohar R., Batool A. Effect of Corporate Governance on Performance of Microfinance Institutions: A Case from Pakistan. Emerging Markets Finance and Trade. 2015; 51(6): 94-106.

28. Mori N., Randøy T., Golesorkhi S. Determinants of Board Structure in Microfinance Institutions: Evidence from East Africa. Journal of Emerging Market Finance. 2013; 12(3):323-365.

29. Mersland R., Strøm R.Ø. Performance and governance in microfinance institutions. Journal of Banking and Finance. 2009; 33:662-669.

30. Perryman Alexa A., Fernando A., Guy D., Tripathy A. Do gender differences persist? An examination of gender diversity on firm performance, risk, and executive compensation. Journal of Business Research. 2016; 69(2): 579-586.

31. Schreiner M., 2002. Aspects of outreach: A framework for discussion of the social benefits of microfinance. Journal of international development. 2002; 14(5): 591-603.

32. Noah M. The Case for Support. Bringing Opportunity to Women. Opportunity International. 2010:1-7. 


\section{Appendix}

\section{Appendix 1}

Table 1. The description of variables

\begin{tabular}{|c|c|c|}
\hline Variable & Name & Method of calculation \\
\hline Return on assets measured & ROA & Net operating income less taxes/average assets \\
\hline Return on equity & $\mathrm{ROE}$ & Net operating income less taxes/average equity \\
\hline Operational self- sufficiency & OSS & $\begin{array}{l}\text { Financial revenue/ (Financial expense }+ \text { impairment loss }+ \\
\text { operating expense) }\end{array}$ \\
\hline Profit margin & Pmargin & Net operating income/Financial revenue \\
\hline Yield on gross portfolio & Yield & $\begin{array}{l}\text { Interest and fees on loan portfolio/gross average loan port- } \\
\text { folio }\end{array}$ \\
\hline Average loan balance & Avloan & Gross loan portfolio/number of portfolios in MFI \\
\hline $\begin{array}{l}\text { Average loan balance per } \\
\text { borrower }\end{array}$ & Avloanborr & Gross loan portfolio/number of current borrowers \\
\hline Number of borrowers & Nborr & $\begin{array}{l}\text { Number of current borrowers; individuals who have multi- } \\
\text { ple loans with an MFI are counted as a single borrower }\end{array}$ \\
\hline $\begin{array}{l}\text { Percentage of women-bor- } \\
\text { rowers }\end{array}$ & wborr_pc & $\begin{array}{l}\text { Number of current borrowers who are women/Number of } \\
\text { current borrowers }\end{array}$ \\
\hline Size of board of directors & board_size & Number of directors in the board \\
\hline $\begin{array}{l}\text { Percentage of women in } \\
\text { board of directors }\end{array}$ & wboard_pc & $\begin{array}{l}\text { Number of women in board of directors/size of the board of } \\
\text { directors }\end{array}$ \\
\hline Female CEO & Wceo & A dummy indicating a female when equal to 1 \\
\hline $\begin{array}{l}\text { Percentage of women in the } \\
\text { management }\end{array}$ & wman_pc & $\begin{array}{l}\text { Number of women in the management/Total number of } \\
\text { managers }\end{array}$ \\
\hline $\begin{array}{l}\text { Portfolio at risk }>90 \text { days } \\
\text { ratio }\end{array}$ & par90 & $\begin{array}{l}\text { The fraction of the portfolio with more than } 90 \text { days in } \\
\text { arrears; Portfolio at risk }>90 \text { days/Loan portfolio, gross }\end{array}$ \\
\hline $\begin{array}{l}\text { Operating expense to loan } \\
\text { portfolio ratio }\end{array}$ & opex_loan & Operating expense/loan portfolio, gross, average \\
\hline Offices & & $\begin{array}{l}\text { The number of staffed points of service and administrative } \\
\text { sites used to deliver or support the delivery of financial } \\
\text { services to microfinance clients }\end{array}$ \\
\hline Age of the MFI & Age & The number of years of MFI since establishment \\
\hline Firm size & firm_size & Ln(assets) \\
\hline $\begin{array}{l}\text { GDP per capita based on } \\
\text { purchasing power parity }\end{array}$ & GDP_PPP & GDP per capita based on purchasing power parity \\
\hline Leverage & Lev & Liabilities to assets ratio of MFI \\
\hline
\end{tabular}


Table 2. Descriptive statistics

\begin{tabular}{|c|c|c|c|c|c|}
\hline Variable & Obs & Mean & Std. Dev. & Min & Max \\
\hline ROA & 839 & 0.047236 & 0.096814 & -0.3112 & 0.602149 \\
\hline OSS & 836 & 1.319406 & 0.665016 & 0.3969 & 8.3036 \\
\hline Pmargin & 823 & 0.150578 & 0.263138 & -1.5198 & 1 \\
\hline yieldnom & 805 & 0.313878 & 0.279051 & 0.0001 & 3.2055 \\
\hline par90 & 816 & 0.047797 & 0.081828 & 0 & 0.738743 \\
\hline Avloan & 836 & 4.654328 & 7.527864 & 0.101474 & 82.43048 \\
\hline wborr_pc & 839 & 0.445017 & 0.203232 & 0.0041 & 1 \\
\hline Nborr & 839 & 17605.64 & 36261.2 & 3 & 357072 \\
\hline opex_loan & 800 & 0.194445 & 0.176598 & 0.0001 & 1.5864 \\
\hline GDP_PPP & 996 & 12.09109 & 6.966864 & 2.08 & 25.261 \\
\hline board_size & 839 & 4.052443 & 1.734011 & 0 & 10 \\
\hline wboard_pc & 839 & 0.315433 & 0.236291 & 0 & 1 \\
\hline wceo & 836 & 0.399522 & 0.490093 & 0 & 1 \\
\hline wman_pc & 839 & 0.500248 & 0.271358 & 0 & 1 \\
\hline wofficer_pc & 839 & 0.48586 & 0.286124 & 0.0052 & 1 \\
\hline offices & 839 & 24.03456 & 55.11106 & 0 & 536 \\
\hline age & 839 & 10.60191 & 5.429856 & 0 & 29 \\
\hline firm_size & 839 & 16.30523 & 2.230847 & 8.844192 & 21.79851 \\
\hline
\end{tabular}




\section{Appendix 2}

Table 3. Correlation matrix

oss lev

par90 wceo

\begin{tabular}{|c|c|c|c|c|c|c|c|c|c|c|c|c|c|}
\hline OSS & 1 & & & & & & & & & & & & \\
\hline Lev & -0.3321 & 1 & & & & & & & & & & & \\
\hline par90 & -0.0842 & -0.0333 & 1 & & & & & & & & & & \\
\hline Wceo & 0.0135 & -0.0542 & -0.1084 & 1 & & & & & & & & & \\
\hline wman_par90 & 0.0109 & -0.0781 & 0.8684 & -0.0586 & 1 & & & & & & & & \\
\hline par90_wceo & -0.0031 & -0.0387 & 0.3133 & 0.5105 & 0.2988 & 1 & & & & & & & \\
\hline wboard_pc & 0.0304 & -0.0637 & -0.0485 & 0.0917 & -0.0125 & -0.0096 & 1 & & & & & & \\
\hline wman_pc & 0.1229 & -0.2221 & 0.062 & 0.1289 & 0.3463 & 0.1166 & 0.2163 & 1 & & & & & \\
\hline wstaff_pc & 0.0355 & -0.04 & 0.1162 & 0.1157 & 0.2048 & 0.091 & 0.3103 & 0.4554 & 1 & & & & \\
\hline board_size & -0.1232 & 0.131 & -0.0167 & 0.0797 & -0.0365 & 0.0362 & 0.1323 & -0.0326 & 0.1313 & 1 & & & \\
\hline firm_size & -0.2377 & 0.5019 & 0.0854 & -0.2002 & -0.0419 & -0.095 & -0.065 & -0.3254 & -0.0171 & 0.3127 & 1 & & \\
\hline opex_loanp $\sim$ t & -0.0118 & -0.1413 & -0.1229 & -0.0432 & -0.1066 & -0.0883 & 0.0743 & 0.0811 & -0.0299 & -0.1369 & -0.299 & 1 & \\
\hline age & -0.1736 & 0.1697 & 0.0644 & 0.0518 & 0.0351 & 0.1247 & -0.0663 & -0.0662 & 0.0222 & 0.3061 & 0.3984 & -0.1941 & 1 \\
\hline GDP_PPP & 0.065 & -0.1202 & 0.1289 & 0.18 & 0.1976 & 0.1662 & 0.025 & 0.2747 & 0.3575 & -0.0513 & -0.0268 & -0.0825 & 0.0546 \\
\hline
\end{tabular}




\section{Appendix 3}

Table 4. The influence of female presence on financial performance measured as profit margin, ROA and ROE

\begin{tabular}{|c|c|c|c|c|c|c|c|}
\hline & (1) & (2) & $(3)^{\bullet}$ & (4) & (5) & (6) & (7) \\
\hline VARIABLES & pmargin & pmargin & Pmargin & ROA & ROA & ROE & ROE \\
\hline \multirow[t]{2}{*}{ lev } & $-0.334^{\star * *}$ & $-0.342^{\star * \star}$ & $-0.306^{\star * *}$ & $-0.0572^{\star * \star}$ & $-0.0608^{\star * *}$ & $0.118^{\star *}$ & $0.106^{\star}$ \\
\hline & $(0.0479)$ & $(0.0479)$ & $(0.0616)$ & $(0.0148)$ & $(0.0148)$ & $(0.0585)$ & $(0.0590)$ \\
\hline \multirow[t]{2}{*}{ par90 } & $-1.274^{\star * *}$ & $-2.045^{\star \star \star}$ & $-1.765^{\star * *}$ & $-0.209^{\star \star \star}$ & $-0.465^{\star * *}$ & -0.294 & $-0.942^{\star *}$ \\
\hline & $(0.171)$ & $(0.314)$ & $(0.265)$ & $(0.0532)$ & $(0.0987)$ & $(0.219)$ & $(0.436)$ \\
\hline \multirow[t]{2}{*}{ wceo } & -0.0361 & 0.00537 & -0.0743 & -0.0118 & -0.00591 & 0.0365 & 0.0117 \\
\hline & $(0.0342)$ & $(0.0309)$ & $(0.0472)$ & $(0.0104)$ & $(0.00934)$ & $(0.0383)$ & $(0.0337)$ \\
\hline \multirow[t]{2}{*}{ par90_wceo } & $0.865^{\star *}$ & & $1.880^{* * *}$ & 0.108 & & -0.686 & \\
\hline & $(0.350)$ & & $(0.519)$ & $(0.110)$ & & $(0.482)$ & \\
\hline \multirow[t]{2}{*}{ wboard_pc } & 0.0480 & 0.0539 & 0.0427 & $0.0255^{\star}$ & $0.0273^{\star}$ & $0.118^{*}$ & $0.125^{\star \star}$ \\
\hline & $(0.0468)$ & $(0.0466)$ & $(0.0649)$ & $(0.0146)$ & $(0.0146)$ & $(0.0609)$ & $(0.0612)$ \\
\hline \multirow[t]{2}{*}{ wman_pc } & 0.0625 & -0.0201 & $0.109^{*}$ & -0.00659 & $-0.0296^{*}$ & -0.0872 & $-0.129^{\star}$ \\
\hline & $(0.0467)$ & $(0.0514)$ & $(0.0654)$ & $(0.0146)$ & $(0.0161)$ & $(0.0601)$ & $(0.0688)$ \\
\hline \multirow[t]{2}{*}{ wstaff_pc } & -0.0786 & -0.0870 & -0.0732 & -0.00553 & -0.00613 & 0.0979 & 0.107 \\
\hline & $(0.0758)$ & $(0.0755)$ & $(0.100)$ & $(0.0236)$ & $(0.0234)$ & $(0.0944)$ & $(0.0949)$ \\
\hline \multirow[t]{2}{*}{ board_size } & -0.00365 & -0.00386 & -0.0107 & 0.00104 & 0.00100 & 0.00361 & 0.00356 \\
\hline & $(0.00844)$ & $(0.00842)$ & $(0.0129)$ & $(0.00258)$ & $(0.00257)$ & $(0.00950)$ & $(0.00957)$ \\
\hline \multirow[t]{2}{*}{ firm_size } & $0.0215^{\star *}$ & $0.0246^{\star * *}$ & 0.0190 & $-0.00664^{\star \star}$ & $-0.00574^{\star \star}$ & $-0.0262^{\star * *}$ & $-0.0243^{\star *}$ \\
\hline & $(0.00896)$ & $(0.00899)$ & $(0.0157)$ & $(0.00273)$ & $(0.00273)$ & $(0.00997)$ & $(0.0101)$ \\
\hline \multirow[t]{2}{*}{ opex_loanport } & $-0.161^{\star * *}$ & $-0.141^{\star *}$ & $-0.256^{\star * *}$ & -0.0120 & -0.00704 & -0.0309 & -0.0247 \\
\hline & $(0.0586)$ & $(0.0584)$ & $(0.0811)$ & $(0.0184)$ & $(0.0183)$ & $(0.0774)$ & $(0.0779)$ \\
\hline \multirow[t]{2}{*}{ age } & -0.00241 & -0.00234 & $-0.00810^{*}$ & $-8.53 e-05$ & $-7.76 e-05$ & 0.00404 & 0.00375 \\
\hline & $(0.00289)$ & $(0.00288)$ & $(0.00427)$ & $(0.000878)$ & $(0.000874)$ & $(0.00317)$ & $(0.00319)$ \\
\hline \multirow[t]{2}{*}{ GDP_PPP } & -0.000287 & -0.000121 & -0.000700 & -0.00120 & -0.00118 & -0.00232 & -0.00251 \\
\hline & $(0.00244)$ & $(0.00243)$ & $(0.00364)$ & $(0.000731)$ & $(0.000728)$ & $(0.00253)$ & $(0.00255)$ \\
\hline \multirow[t]{2}{*}{ wman_par90 } & & $1.770^{\star * *}$ & & & $0.517^{\star * *}$ & & 0.986 \\
\hline & & $(0.505)$ & & & $(0.160)$ & & $(0.746)$ \\
\hline \multirow[t]{2}{*}{ Constant } & 0.128 & 0.108 & 0.245 & $0.209^{* * *}$ & $0.205^{\star \star \star}$ & $0.424^{\star * \star}$ & $0.426^{\star * \star}$ \\
\hline & $(0.138)$ & $(0.138)$ & $(0.232)$ & $(0.0420)$ & $(0.0418)$ & $(0.154)$ & $(0.155)$ \\
\hline
\end{tabular}

- The specification presents the results for firms with lower than average firm size. 


\begin{tabular}{lccccccc} 
& $(1)$ & $(2)$ & $(3)^{*}$ & $(4)$ & $(5)$ & $(6)$ & $(7)$ \\
VARIABLES & pmargin & pmargin & Pmargin & ROA & ROA & ROE & ROE \\
Number of id & 183 & & 124 & 183 & 183 & 183 & 183 \\
Wald chi2 & 110.23 & 117.22 & 84.22 & 62.59 & 72.66 & 24.4 & 23.84 \\
Prob $>$ chi2 & 0.0000 & 0.0000 & 0.0000 & 0.0000 & 0.0000 & 0.0000 & 0.0214 \\
\hline
\end{tabular}

Standard errors in parentheses

${ }^{* * *} \mathrm{p}<0.01,{ }^{* *} \mathrm{p}<0.05,{ }^{*} \mathrm{p}<0.1$.

Table 5. Influence of female presence on financial performance measured as nominal yield on gross portfolio and operating self-sufficiency

\begin{tabular}{|c|c|c|c|c|c|}
\hline & (8) & (9) & (10) & (11) & $(12)^{\bullet}$ \\
\hline VARIABLES & yieldnom & yieldnom & Oss & Oss & Oss \\
\hline \multirow[t]{2}{*}{ Lev } & 0.0178 & 0.0179 & $-0.529 * * *$ & $-0.567 * * *$ & $-0.506^{* * *}$ \\
\hline & $(0.0454)$ & $(0.0458)$ & $(0.107)$ & $(0.107)$ & $(0.143)$ \\
\hline \multirow[t]{2}{*}{ par90 } & -0.324 & -0.241 & $-1.097 * * *$ & $-2.799 * * *$ & $-1.323^{* *}$ \\
\hline & $(0.203)$ & $(0.338)$ & $(0.380)$ & $(0.698)$ & $(0.624)$ \\
\hline \multirow[t]{2}{*}{ Wceo } & -0.0220 & -0.00961 & -0.0796 & $-0.133^{*}$ & -0.0980 \\
\hline & $(0.0304)$ & $(0.0266)$ & $(0.0766)$ & $(0.0690)$ & $(0.109)$ \\
\hline \multirow[t]{2}{*}{ par90_wceo } & 0.309 & & $-1.493 *$ & & -1.569 \\
\hline & $(0.374)$ & & $(0.776)$ & & $(1.222)$ \\
\hline \multirow[t]{2}{*}{ wboard_pc } & $0.0777^{*}$ & $0.0767^{*}$ & -0.144 & -0.134 & -0.205 \\
\hline & $(0.0460)$ & $(0.0461)$ & $(0.104)$ & $(0.104)$ & $(0.152)$ \\
\hline \multirow[t]{2}{*}{ wman_pc } & -0.00156 & -0.00312 & 0.153 & 0.0553 & $0.280^{*}$ \\
\hline & $(0.0455)$ & $(0.0514)$ & $(0.104)$ & $(0.114)$ & $(0.153)$ \\
\hline \multirow[t]{2}{*}{ wstaff_pc } & 0.0216 & 0.0202 & 0.108 & 0.123 & 0.156 \\
\hline & $(0.0722)$ & $(0.0724)$ & $(0.169)$ & $(0.168)$ & $(0.233)$ \\
\hline \multirow[t]{2}{*}{ board_size } & -0.00603 & -0.00601 & -0.0161 & -0.0163 & -0.0453 \\
\hline & $(0.00744)$ & $(0.00748)$ & $(0.0189)$ & $(0.0188)$ & $(0.0297)$ \\
\hline \multirow[t]{2}{*}{ firm_size } & -0.00950 & -0.00962 & -0.00290 & 0.00204 & -0.0179 \\
\hline & $(0.00785)$ & $(0.00792)$ & $(0.0201)$ & $(0.0201)$ & $(0.0363)$ \\
\hline \multirow[t]{2}{*}{ opex_loanport } & $0.698 * * *$ & $0.699 * * *$ & $-0.347 * * *$ & $-0.339 * * *$ & $-0.468^{* *}$ \\
\hline & $(0.0582)$ & $(0.0585)$ & $(0.130)$ & $(0.130)$ & $(0.189)$ \\
\hline \multirow[t]{2}{*}{ Age } & $-0.00513 * *$ & $-0.00500^{* *}$ & $-0.0155^{* *}$ & $-0.0156^{* *}$ & $-0.0263 * * *$ \\
\hline & $(0.00250)$ & $(0.00251)$ & $(0.00647)$ & $(0.00643)$ & $(0.00982)$ \\
\hline
\end{tabular}

\footnotetext{
- The specification presents the results for firms with lower than average firm size.
} 


\begin{tabular}{|c|c|c|c|c|c|}
\hline GDP_PPP & $-0.00394 *$ & $-0.00397 *$ & 0.00309 & 0.00266 & 0.00344 \\
\hline & $(0.00204)$ & $(0.00205)$ & $(0.00548)$ & $(0.00544)$ & $(0.00834)$ \\
\hline \multirow[t]{2}{*}{ wman_par90 } & & 0.00755 & & $2.494 * *$ & \\
\hline & & $(0.542)$ & & $(1.122)$ & \\
\hline \multirow[t]{2}{*}{ Constant } & $0.432 * * *$ & $0.431 * * *$ & $1.962^{* * *}$ & $1.968 * * *$ & $2.339 * * *$ \\
\hline & $(0.121)$ & $(0.121)$ & $(0.309)$ & $(0.307)$ & $(0.538)$ \\
\hline Observations & 766 & 766 & 768 & 768 & 470 \\
\hline Number of id & 182 & 182 & 183 & 183 & 124 \\
\hline Wald chi2 & 221.14 & 218.31 & 80.41 & 82.04 & 54.56 \\
\hline Prob $>$ chi2 & 0.0000 & 0.0000 & 0.0000 & 0.0000 & 0.0000 \\
\hline
\end{tabular}

Standard errors in parentheses

${ }^{* * *} \mathrm{p}<0.01,{ }^{* *} \mathrm{p}<0.05,{ }^{*} \mathrm{p}<0.1$.

Table 6. The summary statistics on loans qualities, dependent on gender diversity in boards in directors.

\begin{tabular}{|c|c|c|c|c|c|}
\hline Variable & Obs & Mean & Std. Dev. & Min & Max \\
\hline \multicolumn{6}{|c|}{ Where the percentage of women in boards of directors is more than $40 \%$} \\
\hline number_loans & 167 & 23726.72 & 54801.45 & 47 & 357072 \\
\hline average_loan per borrower & 167 & 0.836196 & 0.904536 & 0.0105 & 4.5578 \\
\hline avloan & 167 & 2.707704 & 3.459931 & 0.131615 & 17.6118 \\
\hline number_borrowers & 167 & 22.79678 & 53.28309 & 0.047 & 357.072 \\
\hline
\end{tabular}

Where the percentage of women in boards of directors is less than $16.6 \%$

\begin{tabular}{|c|c|c|c|c|c|}
\hline number_loans & 203 & 16914.01 & 40377.03 & 10 & 252194 \\
\hline average_loan per borrower & 202 & 0.997211 & 1.097821 & 0.068 & 6.5525 \\
\hline avloan & 203 & 4.541215 & 6.715681 & 0.101474 & 44.94717 \\
\hline number_borrowers & 203 & 14.49351 & 33.82759 & 0.005 & 180.207 \\
\hline
\end{tabular}




\section{Appendix 4}

Table 7. Influence of female presence on social performance measured as average loan size, average loan per borrower

\begin{tabular}{|c|c|c|c|c|c|c|}
\hline VARIABLES & $\begin{array}{c}\text { (1) } \\
\text { avloan }\end{array}$ & $\begin{array}{c}(2) \\
\text { avloan }\end{array}$ & $\begin{array}{c}(3) \\
\text { avloan }\end{array}$ & $\begin{array}{c}\text { (4) } \\
\text { avloanborr }\end{array}$ & $\begin{array}{c}\text { (5) } \\
\text { avloanborr }\end{array}$ & $\begin{array}{c}\text { (6) } \\
\text { avloanborr }\end{array}$ \\
\hline \multirow[t]{2}{*}{ Wceo } & -0.454 & 0.214 & -0.642 & 0.0538 & -0.195 & $0.192^{*}$ \\
\hline & $(0.561)$ & $(0.553)$ & $(1.772)$ & $(0.0932)$ & $(0.156)$ & $(0.115)$ \\
\hline \multirow[t]{2}{*}{ wboard_pc } & -0.299 & -0.210 & -0.103 & -0.146 & $-0.413^{* *}$ & 0.161 \\
\hline & $(0.754)$ & $(0.765)$ & $(2.057)$ & $(0.122)$ & $(0.185)$ & $(0.161)$ \\
\hline \multirow[t]{2}{*}{ wman_pc } & $1.745 * * *$ & 0.977 & $3.709 * *$ & 0.0318 & 0.143 & -0.0650 \\
\hline & $(0.659)$ & $(0.672)$ & (1.814) & $(0.108)$ & $(0.158)$ & $(0.147)$ \\
\hline \multirow[t]{2}{*}{ wstaff_pc } & 0.337 & -0.448 & $10.97 * *$ & 0.0174 & -0.00808 & -0.227 \\
\hline & $(1.221)$ & $(1.157)$ & $(4.940)$ & $(0.201)$ & $(0.384)$ & $(0.247)$ \\
\hline \multirow[t]{2}{*}{ board_size } & 0.169 & -0.0796 & 0.485 & -0.00969 & 0.00323 & -0.0190 \\
\hline & $(0.147)$ & $(0.161)$ & $(0.325)$ & $(0.0239)$ & $(0.0313)$ & $(0.0341)$ \\
\hline \multirow[t]{2}{*}{ firm_size } & $0.572 * * *$ & 0.159 & $2.305^{* * *}$ & $0.211^{* * *}$ & $0.431^{* * *}$ & $0.237 * * *$ \\
\hline & $(0.179)$ & $(0.194)$ & $(0.771)$ & $(0.0292)$ & $(0.0610)$ & $(0.0446)$ \\
\hline \multirow[t]{2}{*}{ opex_loanport } & $-1.762 * *$ & & & & & \\
\hline & $(0.867)$ & & & & & \\
\hline \multirow[t]{2}{*}{ Age } & -0.0606 & -0.0759 & 0.0284 & $-0.0220^{* *}$ & $-0.0395 * * *$ & $-0.0232^{*}$ \\
\hline & $(0.0591)$ & $(0.0610)$ & $(0.144)$ & $(0.00984)$ & $(0.0140)$ & $(0.0138)$ \\
\hline \multirow[t]{2}{*}{ GDP_PPP } & $0.190 * * *$ & $0.266 * * *$ & -0.0387 & $-0.0302 * * *$ & $-0.0501 * * *$ & $-0.0249 * *$ \\
\hline & $(0.0554)$ & $(0.0565)$ & $(0.138)$ & $(0.00914)$ & $(0.0133)$ & $(0.0121)$ \\
\hline \multirow[t]{2}{*}{ L.par90 } & $7.121 * * *$ & $5.562 * *$ & 8.576 & 0.146 & 0.719 & $-0.902 *$ \\
\hline & $(2.496)$ & $(2.379)$ & $(6.772)$ & $(0.414)$ & $(0.662)$ & $(0.538)$ \\
\hline \multirow[t]{2}{*}{ Offices } & -0.00783 & -0.0239 & $-0.0156^{*}$ & $-0.00207 * *$ & $-0.00261 * *$ & -0.00378 \\
\hline & $(0.00614)$ & $(0.0146)$ & $(0.00838)$ & $(0.00102)$ & $(0.00108)$ & $(0.00429)$ \\
\hline \multirow[t]{2}{*}{ Constant } & $-7.654 * * *$ & -1.236 & $-45.86 * * *$ & $-1.786 * * *$ & $-5.351 * * *$ & $-1.976^{* * *}$ \\
\hline & $(2.946)$ & $(3.045)$ & $(13.84)$ & $(0.476)$ & $(1.050)$ & $(0.667)$ \\
\hline Observations & 586 & 448 & 161 & 606 & 321 & 274 \\
\hline Number of id & 184 & 149 & 52 & 192 & 100 & 103 \\
\hline Wald chi2 & 52.96 & 39 & 33.9 & 72.82 & 83.63 & 41.52 \\
\hline Prob $>$ chi 2 & 0.0000 & 0.0000 & 0.0004 & 0.0000 & 0.0000 & 0.0000 \\
\hline
\end{tabular}

Standard errors in parentheses

${ }^{* * *} \mathrm{p}<0.01,{ }^{* *} \mathrm{p}<0.05,{ }^{*} \mathrm{p}<0.1$. 
Table 8. Influence of female presence on social performance measured as number of borrowers, growth in number of borrowers and percentage of female borrowers

\begin{tabular}{|c|c|c|c|c|}
\hline & (7) & (8) & (9) & (10) \\
\hline VARIABLES & nborr & grnborr & grnborr & wborr_pc \\
\hline \multirow[t]{2}{*}{ wceo } & $-8.209 * * *$ & -0.145 & $0.344 * *$ & 0.0191 \\
\hline & $(2.740)$ & $(0.795)$ & $(0.155)$ & $(0.0218)$ \\
\hline \multirow[t]{2}{*}{ wboard_pc } & -2.477 & $-3.082 *$ & -0.213 & $0.0637 * *$ \\
\hline & $(3.880)$ & $(1.661)$ & $(0.314)$ & $(0.0313)$ \\
\hline \multirow[t]{2}{*}{ wman_pc } & -5.588 & -0.250 & 0.223 & -0.0361 \\
\hline & $(3.477)$ & $(1.669)$ & $(0.327)$ & $(0.0281)$ \\
\hline \multirow[t]{2}{*}{ wstaff_pc } & 6.580 & 1.257 & -0.350 & $0.188 * * *$ \\
\hline & $(6.281)$ & $(2.504)$ & $(0.458)$ & $(0.0505)$ \\
\hline \multirow[t]{2}{*}{ board_size } & 0.644 & $0.402 *$ & -0.00118 & -0.00465 \\
\hline & $(0.718)$ & $(0.236)$ & $(0.0476)$ & $(0.00573)$ \\
\hline \multirow[t]{2}{*}{ firm_size } & $5.263 * * *$ & 0.0658 & 0.0738 & -0.00281 \\
\hline & $(0.823)$ & $(0.229)$ & $(0.0580)$ & $(0.00649)$ \\
\hline
\end{tabular}

opex_loanport

\begin{tabular}{|c|c|c|c|c|}
\hline age & $1.049 * * *$ & -0.112 & $-0.0440 * * *$ & $-0.00488 * *$ \\
\hline & $(0.280)$ & $(0.0780)$ & $(0.0155)$ & $(0.00221)$ \\
\hline \multirow[t]{2}{*}{ GDP_PPP } & 0.0244 & 0.00635 & $-0.0280 * *$ & $-0.00349^{*}$ \\
\hline & $(0.239)$ & $(0.0599)$ & $(0.0121)$ & $(0.00187)$ \\
\hline \multirow[t]{2}{*}{ L.par90 } & -19.59 & $14.13 * * *$ & $1.869^{*}$ & 0.112 \\
\hline & $(12.21)$ & $(4.829)$ & $(1.052)$ & $(0.0978)$ \\
\hline \multirow[t]{2}{*}{ offices } & $0.285 * * *$ & -0.000317 & 0.00193 & $0.000372 *$ \\
\hline & $(0.0286)$ & $(0.00725)$ & $(0.00670)$ & $(0.000225)$ \\
\hline \multirow[t]{2}{*}{ Constant } & $-84.35^{* * *}$ & -0.746 & -0.123 & $0.486 * * *$ \\
\hline & (13.38) & $(3.802)$ & $(0.916)$ & $(0.106)$ \\
\hline Observations & 609 & 609 & 446 & 609 \\
\hline Number of id & 193 & 193 & 149 & 193 \\
\hline Wald chi2 & 350.37 & 16.45 & 20.98 & 36.98 \\
\hline Prob $>$ chi2 & 0.0000 & 0.0874 & 0.0213 & 0.0001 \\
\hline
\end{tabular}

Standard errors in parentheses

${ }^{* * *} \mathrm{p}<0.01,{ }^{* *} \mathrm{p}<0.05,{ }^{*} \mathrm{p}<0.1$. 